\title{
Innovative tools for developing soft skills in the context of education transformation
}

\author{
Alvina Panfilova ${ }^{1}$, and Lyubov Larchenko ${ }^{1}$ \\ ${ }^{1}$ Herzen University, 48 Moika Embankment, Saint Petersburg, Russia
}

\begin{abstract}
The purpose of the article is to substantiate the use of modern educational technologies, means and tools of influence to achieve the desired result in any field of education, providing specialists with competitiveness and personnel leadership in the digital era. To analyze the current situation in the education system and develop proposals for their improvement, this article uses the results of many years of research obtained within the framework of the author's scientific and pedagogical school on the development of the communicative potential of a future specialist and its implementation in future practical professional activities. Particular attention is paid to the study of the effectiveness of interactive technologies aimed on the development of students' cross-cutting competencies and communication skills, as well as modern teaching trends, such as networking and edutainment, the value of which is allowing specialists to better navigate in a rapidly changing world, in various new directions, modern studying courses and technologies and understand the flows of new information. The authors of the article studied in what directions, with the use of what educational technologies it is necessary to develop skills that will be in demand in the next decades.
\end{abstract}

\section{Introduction}

In the current historical period, the external environment is characterized by both positive blurring of boundaries between knowledge flows, bright scientific discoveries, rapid technological breakthroughs, and negative factors - a new round of confrontation between world powers, global economic crises, large-scale social and environmental shocks. All of this affects human resource management. This is due to the fact that in the age of rapid changes, competition and ever-increasing demands and requirements for the modern man, each person is faced with at least two problems that require analysis and solution. One of them is psychological, which is exhausting uncertainty, chronic tension, anxiety, stress caused by the lag of internal changes such as knowledge, skills and personal qualities, from external changes - technologies, trends, needs of society, management, entrepreneurship and business. In its turn, this problem gives a rise to an equally disturbing methodological problem, that is, determining what skills specialists need in the face of changes in the first place, and how to organize an effective technological process of self-learning for an adult in order to remain competitive and in demand.

The concept of "technology", which came to us along with the development of computer technology and the introduction of new computer technologies, is more and more 
often found in the literature, but even today, teaching specialists are faced with the question of what makes it possible to achieve the effectiveness of learning: strategy or technology? In this article, we do not discuss this problem, since the authors are interested in technology as a learning tool. However, for a clearer understanding, we will define the terms. A learning strategy is purposeful thinking and behavior aimed to memorize and understand new information in the learning process; training models that are aimed at developing competencies by means of specially designed training programs. And teaching technology is an educational technology, a set of scientifically and practically grounded methods, means and tools of influence to achieve the desired result in any field of education. Learning technology involves clearly defined steps (route map - technological operations), each of those creates a micromodel of the entire educational process, that is, it has its own purpose, content, means, rules of use and result.

The difference between "learning strategy" and "learning technology" is that the former answers the question "What are we doing to achieve certain learning goals?" The second answers the question "How will we act to effectively achieve the learning objective, that is to form new competencies, develop soft skills?"[1].

Many experts in the field of competence, in particular, Chris Argyris argue that today even the most capable people work ineffectively, especially in a team. In our opinion, this is due to the underdevelopment of meta-skills, but also to the fact that people who are absorbed in their daily work, not noticing changes, often fall into captivity of behavioral patterns, stereotypes that were successfully used in the past, and do not understand that they are not effective in new, rapidly changing conditions. It seems that much of the turmoil prevailing in the 21 st century stems from people trying to do today's work with yesterday's tools. Based on this problem, the authors in the presented article tried to answer the question: "What modern tools are in demand in practice and what technologies develop them?"

\section{Materials and research methods}

To analyze the current situation in the system of humanitarian education, this article uses the results of pedagogical research obtained by the supervisor and participant-researchers in the framework of the authorized scientific and pedagogical school "Intensive technologies as an effective tool for the development of professional competencies of future managers" specialized on the problems of improving the communicative potential of a future specialist and his or her implementation under the influence of turbulence and negative factors in the short term and possible negative consequences in future practical professional activities. The development of the pedagogical experiment, its approbation, analysis, systematization of the observed results and the diagnosis of changes in the development of communicative (including interactive and perceptual) skills took place during the 2-year training of the participants in the creative workshop "Game-technical management" 2018-2019 and, at the same time, students studying in a standard mode (majors: Management of Additional Education (full-time students) and Human Resources Management (part-time students).

To understand the problem, the authors also used a complex of general scientific and special research methods, including an abstract-logical method, content analysis of materials on role-playing, innovative, simulation games and catastrophe games conducted in the workshop, comparative analysis of results, testing and interviewing, participant observation, synthesis and other.

In addition, the skills and abilities of the manifestation of communicative competence in business communication were determined. As a result of the practice observation and analysis of literature devoted to this problem, it was determined that communication skills and abilities are manifested, first of all, through the ability to conduct negotiation and a 
small conversation, such as small talks, consultation; through the ability to work in a team and carry out cooperation, partnerships; through the ability to conduct an effective presentation and self-presentation, including public speaking in different verbal genres (report, lecture, participation in discussion, dispute, polemics).

As the content analysis of the literature on the problem has shown, one of the educational trends and significant factors that should determine the country's personnel policy in the 21 st century, in the opinion of many experts, is the development of crosscutting competencies, including soft skills, which are today described by synonyms, such as: "flexible skills "," skills of the 21 st century "," universal competencies ", "interdisciplinary skills", "over-professional skills", "metaskills ". In previous years, they all were called metaskills.

Metaskills are usually not directly related to professional specialization and allow professionals and organizations to collectively manage their basic skills in the face of unforeseen circumstances. If they are developed, then they allow their owners to adapt their knowledge to new circumstances, goals and objectives. In a company of instinctive behavior, in which the requirements for the knowledge and experience of employees change almost daily, the experts say that it is not the employee's knowledge but the ability to learn that will play a primary role $[2,3]$. We will use the term soft skills further in the article.

An analysis of the speeches of specialists at economic forums and international symposia and seminars also showed that at present, the division of competencies into two types is becoming especially popular: hard skills - hard competencies / skills and soft skills - flexible or soft competencies / skills. Analysis of the literature also shows that the terminology arose by analogy with the English terms "hardware" and "software". At the same time, a computer is a kind of material object that can be felt, but without software its work is impossible, the same can be said about the skills that experts call "hard" skills [4].

Term hard skills, as a rule, include those competencies that are important for performing a certain work function (organization, planning, control, etc.) To teach such skills, it is necessary to master knowledge and instructions, and you can determine the quality of training and the level of mastering a skill using special tasks and tests. Examples of such skills: typing on a computer, reading, mathematics, knowledge of a foreign language, using computer programs, etc.

However, in this article, the authors are mainly interested in soft skills, that is, a wide group of socio-psychological skills, a complex of universal (over-professional) skills that are responsible for successful participation in the work process, high productivity and are cross-cutting, meta-skills, that is, are not related with a specific subject area. As practice shows, such skills are quite difficult to measure with quantitative indicators and traditional tests. It is no coincidence that specialists who develop competencies call them personal qualities, because they depend on the character of a person and, as a rule, are acquired with personal experience, and with age, they are more difficult to correct and develop, but their need for professional activity in any area is obvious. The list of such qualities and skills may vary depending on the tasks facing a particular specialist and include, for example, such as: analytical, predictive and creative thinking, communication, the ability to negotiate, the desire to acquire new knowledge and self-development, self-organization, skills lines, developed social and emotional intelligence and much more. As you can see, communication skills are included in this list by many specialists in the field of human relations, marketing and promotion of goods and services, in working with clients and business partners are considered key and most in demand in the next decade $[4,5]$. 


\section{Analysis of the effectiveness of tools and technologies of modern higher education}

If we assume that soft skills are developed in a person in the process of working on himself/herself and in the process of interacting with other people, then the success of mastering soft skills largely depends on how motivated and purposeful a person will be to do this. At the same time, the analysis of practice shows that, despite the strong demand from employers, the majority of working specialists only slightly improve their soft skills and, therefore, cannot match the "demand of the century" - possession of a complex of nonspecialized, but important for a career and success in life soft skills that are responsible for high performance and are "cross-cutting", not related to a specific subject area. Therefore, in order to address the issue of sot skills development, it was necessary to answer questions such as:

- how are cross-cutting skills developed in the system of higher education today?

- what forms, tools and technologies are used for training?

- what is the readiness of teachers of educational institutions and the system of advanced training to introduce innovative technologies (interactive, creative, heuristic) into the educational process?

- is it possible to develop soft skills in the process of professional activity? And why do firms require them from their employees?

The empirical basis of the study for answering the questions posed was the experience of developing soft skills among students of the Institute of Economics and Management at Herzen State Pedagogical University (Department of Social Management). An analysis of the curriculum showed that despite the fact that the soft skills development is becoming more and more relevant, the educational institutions continue to teach mainly hard skills, key professional competencies and often only using traditional methods: lectures, seminars, practical exercises. At the same time, for example, in the human resource management system, it has been proven that a specialist can be organized and responsible, but if, in addition, s/he does not have special professional skills, then s/he will not be able to effectively perform his or her functions, and if s/he does not have developed soft skills. As it was mentioned above in the conditions of changes such individuals will not be able to achieve success and will not make a career, which will undoubtedly affect the economic potential of society as a whole [7,8,9].

In the modern society, economic and technological factors have changed significantly, which also influenced the way of people's life. In this regard, the demand for new individual and collective skills has come to the global professional employment market. This idea was formulated at the presentation of the session "Youth 2030. The Image of the Future", held as part of the World Festival of Youth and Students. It was noted that the future will belong to those people who will be able to combine various knowledge and skills, will be able to combine them and will continue to accumulate them throughout life, that is, the paradigm: "education for life", is changing to the paradigm - "education throughout all life" [10].

However, our analysis of higher education shows that university graduates, even those who have done communication courses, gained them in homeopathic doses ( 72 ac. hours full-time students' curriculum, 36 ac. hours - part-time students' curriculum). Despite the applying interactive technologies, the necessary time is not provided. We still need more academic hours to finish learning to master even professional communication skills: the ability to speak and listen clearly, ask questions and answer them, maintain feedback, effectively participate in disputes, discussions, polemics, and make presentations.

This is evidenced by our research conducted in 2019 with full-time undergraduate students, specialization Additional Education and part-time undergraduate students, 
specialization Human Resources Management. In total, 43 last year undergraduate students were interviewed. 23 students have studied for 2 years in the creative workshop "Gametechnical Management".

To identify the effectiveness of the use of interactive technologies for the development of managerial skills, the following methods were used: K. Thomas's method - selfassessment of interaction strategies in a situation of conflict of opinions; the method of independent group assessment based on the system of objective indicators of its game activity in the learning process (the success of the team in completing educational tasks, work based on intensive discussion technologies, the use of effective interaction strategies the method of "independent characteristics"). In addition to the above, the determination of the communicative competence of students, manifested at the beginning of interactive learning, was also carried out on the basis of included observation (fixation of non-verbal signals, diagnosis of sensory channels, establishment of feedback through post-game discussion, debriefing, reflection, sharing and deroling) and the implementation of expert assessments by "competent judges" from among the trainees themselves.

The need to determine the effectiveness of learning with the help of interactive tools used in the educational process required approbation of an experimental registration method for analyzing the multi-step process of developing communicative and interactive skills in the process of game interaction. For this purpose, a didactic experiment was organized, revealing the level of low and high learning efficiency and the conditions that affect the final characteristics.

As a result, $52 \%$ of them developed communication skills at a high level, $46 \%$ - at an average level and $2 \%$ did not notice any changes. However, it should be noted that undergraduate and graduate students who come to the workshop are distinguished by a priori rich personal potential: communication skills, constructive interaction skills, leadership and presentation capabilities.

For those who did not study in the workshop - 20 people, a high level of communication skills was noted only in $7 \%$ of students, in $46 \%$ the skills only reached an intermediate level, and the rest showed no changes.

Almost the same result was for presentation skills. In the workshop, thanks to the use of gaming technologies, interactive skills such as teamwork, group decision-making, constructive interaction, were developed by students of the experimental group in $67 \%$; in the control group only $12 \%$ of students showed positive results. The data also indicate that the majority of graduates who do not study in special interactive workshops (when applying for a job) do not have sufficiently developed communication skills, which experts attribute to $4 \mathrm{C}$-s - these are Communication, Creativity, Command interaction and Critical thinking. They are in demand in the modern labor market as soft skills, cross-cutting competencies, that is, not relevant to specific courses $[11,12]$.

Thus, a local study of communication skills in the system of training future leaders showed that the development of competencies occurs as a result of one course, which is taught mainly by traditional technologies and well-known methods of enhancing the educational process, such as role-playing games, trainings, case study methods, discussions and project designing. At the same time, the amount of hours is minimal, not enough; teachers practically do not know soft skills development tools required in practice.

As follows from the above, the personnel training system today is not ready to develop cross-cutting competencies. How to tackle this problem to help searching for employment in terms of innovative changes and avoid stress and emotional tension? How and where to get the opportunity to develop these new skills?

In the next section of the article, we will focus on such technologies that comprehensively develop communication skills (contact establishing, conducting a conversation, the ability to interact together while making a decision, feedback skills: 
questions and answers, creative search for new ideas), namely: edutainment and networking.

\section{Application of innovative tools for the development of soft skills as a necessary condition for being competitive and in demand}

The analysis of the soft skills development problem shows that in recent years, training companies and assessment centers have made a great contribution to the improvement of soft skills, widely applying a variety of interactive technologies to diagnose the potential and develop specialists. These are, first of all, trainings, which can include a whole range of game-technical simulation and non-simulation technologies: exercises, cases, games, brainstorming sessions, and group discussions.

What skills are these training centers focused on? For example, when diagnosing and / or training an applicant for the position of a manager-facilitator (with an approximate meaning of "mediator"), as evidenced by the analysis of practice, these are soft skills such as interpersonal responsiveness, tolerance, communication skills, social intelligence, responsibility, possession of various interaction strategies, team management ability, the ability to cooperate and manage conflicts [13]. As you can see, the development of communication skills, that is, the ability to establish contacts and maintain acquaintance, as well as interaction strategies, are the components of most modern trainings in business practice.

It also seems that the most important indicator of changes in the education system, in our opinion, was the emergence of the concept "edutainment" and other new forms of organizing learning activities, such game trends as: gamestorming, foresight technology, workshop, escape room, networking and educational quests. It all required new coaches and educators playing new roles, such as moderator, facilitator, mentor, game technician, tutor, coach and others. In connection with the foregoing, we can assume that "edtainment" is a new fashion trend in the modern market of educational and leisure services.

The concept "edutainment" (education and entertainment), was first used in 1973, in a report for the National Geographic Society, by Robert Hayman and since that time, has become widespread in pedagogy [14]. Speaking about edutainment, A. V. Popov, for example, uses the concept of "learning as entertainment". According to the author, "learning as entertainment" is an effective acquiring of the world in a playful form, since through entertainment not only awareness of a certain subject is established, but at the same time an emotional connection between the student and the subject being studied [15]. The analysis of the training system for personnel of organizations allows us to highlight the features of edutainment technology, such as: practical validity (training is more successful with the expressed usefulness of the knowledge acquired); additional training (including independent); distributed learning (a network that provides wide access to educational resources of many users, in which all students learn in different ways, at different periods of time, in a different territorial space) [16].

Experts believe that to describe the current field of "edutainment" it is advisable to divide it into two large parts. The first concerns the way of transmitting information, developing skills and abilities in those who are not too motivated. Therefore, entertainment is used here only to activate the student. The second area is when the learning process itself is understood as a special show, a process of entertainment and getting positive emotions, that is, learning with serotonin (the hormone of happiness), and any sources, including those that are not educational or teaching materials, become information. As for the perception, in the first case the perception is passive, in the second it is more perception of 
a researcher. One of the most popular technologies for joyful learning, in the edutainment format, is The World Cafe technology, which is a method of group discussions, in which informal communication between participants over a cup of coffee. There is a phased change of playing places and a transition to another "host" of the table, with the constant working out of new thoughts and ideas. In this sense, the process turns from teaching, when a comprehensive view of the issue under discussion is formed, into a tool for creating a context for joint activities, developing communication skills.

As practice shows, interactive learning using The World Cafe approach allows in a short period of time to unite completely different people, to avoid possible misunderstandings and overcome the reluctance to work together. An informal friendly atmosphere contributes to the relaxation and openness of participants in the process of analyzing the problem, diagnosing its symptoms and causes, generating ideas and subsequent discussion, relieves possible anxiety and stiffness. During this activity a free conversation is allowed and even encouraged. This technology takes a little time, but when discussing an urgent, sometimes complex, problem, it is very effective, since the participants very quickly adapt to each other, even when changing places and actively propose a variety of ideas, proposals, miniprojects. As a result, for the passage of 6 stages (each for 10 minutes), the hosts of the table accumulate a large innovative material, which allows, after analysis and discussion, to develop and formulate, several really new and practically useful ideas [17].

Thus, the experience of conducting "edutainment" technology allows us to speak about its wide applicability for the development of soft skills in adults due to the following obvious advantages, such as:

Involving hobby and entertainment. Since the entertainment in the educational game leads to pleasure, at the same time forming a persistent interest to the learning process, it relieves the psychological burden from the educational process.

Using playful approach;

Following modern trends - when using the current capabilities of modern technologies, such as electronic systems (electronic textbooks, network versions of museum exhibitions), personal computer systems (computer or video games, electronic simulators, electronic encyclopedias) and web technologies (e-mail, web quests, wikis, blogs, chats, video conferencing);

Applying educational programs in multimedia format and many other means, maximum involvement of students in the educational process is achieved; open space - parks, stadiums, museums, cafes, clubs, offices for organizing interactive communication: dialogue and polylogue, the purpose of which is to maximally facilitate the analysis of events in an informal setting, maintaining an emotional connection with the learning object $[18,19]$.

An important technology that develops communication skills is the technology of networking, which has become widespread in the last decade. This social and professional activity is aimed at ensuring that, with the help of a circle of friends and acquaintances who work or have connections in a particular area, as quickly and efficiently as possible solve complex life tasks (treatment, employment) and business issues (find clients, hire the best employees, attract investors). At the same time, the essence of networking is building trusting and long-term relationships with people and mutual assistance. At the same time, the essence of networking is building trusting and long-term relationships with people and mutual assistance. It should be noted that this "new" technology is not "new" for our country, since back in the 60s and 70s of the XXth century, the ability to establish contacts with the right people was well developed, but it was not a learning technology and in this sense, this technology is new. In addition to the above, it should be noted that modern youth have great difficulties in initiating real contacts, since most of them communicate from early childhood mainly remotely. 
An analysis of the literature shows that the concept of "networking" is based on the socalled theory of six handshakes, developed in the 1969-s by American social psychologists Stanley Milgram and Jeffrey Travers. Its essence is that each of us is indirectly acquainted with any other inhabitant of the planet through a chain of common acquaintances. On average, this chain consists of six people. Social networking (business needs and active development of social networks on the Internet) and personal networking, when the goals of using networking tools are based on the personal aspirations and values of the individual are distinguished. As a rule, these contacts are used to form a circle of friends, to establish friendly relations with new people. In Russia, the largest number of networking meetings is organized by the Business Family. Their branches are represented in 5 countries of the world: Russia, Kazakhstan, Belarus, Switzerland and Great Britain. The daily use of networking practice can significantly change the social circle - and lead to significant improvements in the life of the person who uses networking. Today, networking and edutainment are already included in the curriculum of leading business schools as separate disciplines [20]. And this is natural, because it is a wide network of connections, acquaintances and contacts that brings success in business, that is, developed soft skills.

\section{Conclusion}

Thus, as the modern world is characterized by instability, variability, lack of sequence of events, competition in all types of activities, as well as new trends of multimedia and information technology, applying new sign systems on the screens, educational strategies must correspond to the level of development of society and the achievements of scientific and technological progress, so that the younger generation is professionally in demand on the world labor market. However, the study showed:

1. The majority of graduates and already working specialists often do not possess crosscutting, communication skills;

2. The personnel training system today is not ready to develop cross-cutting competencies, both due to the small number of hours and courses that develop communication skills, and also due to the lack of ownership of modern interactive technologies by the teaching staff, - this was confirmed by specialists at all intellectual forums held in recent years;

3. Training of specialists in the system of advanced training and in the system of additional education also lags behind the requirements of the time;

4. Many modern interactive trends are implemented only in the system of business training and commercial courses.

From the above, it is obvious that the development of cross-cutting skills largely depends on the interactive competence of teaching personnel, the orientation of the advanced training system and additional education to the introduction of modern training trends focused on the development of cross-cutting competencies and teaching new types of educational activities, such as mentoring, facilitation, moderation., tutoring, coaching, etc. At the same time, the practice of teaching adults shows that motivation, dedication and active participation of the specialists themselves, who want to be competitive and in demand, are needed. Mastering the cross-cutting skills of the 21 st century that meet the requirements of educational innovation trends, you need to learn every day, analyze your mistakes and miscalculations, work on yourself, enriching the communicative experience of activity.

Modern university education around the world is undergoing an intense paradigm shift. This process, which significantly changes the appearance of the university as an educational and cultural environment, raises the question of updating the strategies, goals of teaching, content, technologies of university education. The need to move from the paradigm of 
"education for life" is changing to the paradigm - "education throughout life", which is felt by everyone who is associated with the educational process, but, above all, students, specialists and teachers of higher education.

The article discusses the main questions, on the solution of which the career of future specialists depends: what should be the new educational practice? What skills to develop in the future? How to teach today to achieve the desired result? The authors of the article made an attempt to show in what directions, with the use of what educational technologies it is necessary to develop skills that will be in demand in the next decades.

\section{References}

1. G. Selevko, Sovremennye obrazovatelnye tehnologii: Uchebnoe posobie. (1998)

2. A. Ivonina, O. Chulanova, Yu. Davletshina, Sovremennye napravleniya teoreticheskih i metodicheskih razrabotok v oblasti upravleniya: rol' soft-skills i hard skills v professional'nom i kar'ernom razvitii sotrudnikov. Internet-journal «NAUKOVEDENIE». 9, №1. (2017).

Access: http://naukovedenie.ru/PDF/90EVN117.pdf

3. T. Koulopoulos, Upravlenie znanijami. Eksmo, Moskva (2008).

4. A. Panfilova, Tekhnologii razvitiya analiticheskogo potenciala studentov v igrovom interaktivnom obuchenii. «Innovatsii», 9 (251) 107-109 (2019)

5. A. Panfilova, S. Mihal'chenko, Razvitie emocional'nogo intellekta kak sostavlyayushchej social'noj kompetentnosti menedzherov // Chelovek i obrazovanie. 4 (37). (2013)

6. P. Shchedrovickij, Rol' metodologicheskogo myshleniya v stanovlenii sovremennyh "skvoznyh" ("pronizyvayushchih") kompetencij i kapitalizacii chelovecheskih resursov // Pedagogika razvitiya: 10th Vseros. konf. Krasnoyarsk. URL: http://conf.ippd.ru. (2003)

7. N. Loginova, A. Semenihin, S. Sychyova, Razvitie predprinimatel'skih kompetencij pri obuchenii menedzhmentu v social'noj sfere. (2019)

8. L. Larchenko, M. Kiseleva, O. Derevianko, Industrial Innovation Clusters of SaintPetersburg: Problems and Development Prospects. SPBPU IDE '19: International Scientific Conference on Innovations in Digital Economy. Saint Petersburg Russian Federation. Article No.: 57. (2020)

9. L. Larchenko, L. Kuramshina, Transition to a circular economy model as an alternative option of solving the problem of solid waste utilization // E3S Web of Conferences : International Conference on Efficient Production and Processing, ICEPP 2020, 161. Article 01108. (2020)

10. A. Trege, Gid po soft skills: kak razvivat' klyuchevye navyki budushchego. Access: https://www.rbc.ru/trends/education/5e8ee8969a7947112c075b6811. Innovacionnoe upravlenie chelovecheskimi resursami v obrazovatel'nyh uchrezhdeniyah. SPb. (2014)

11. I. Al'bickaya, A. Kosyakov. Chto takoe soft skills, i pochemu oni stanovyatsya bolee vazhnymi, chem hard skills. Kadrovaya sluzhba i upravlenie personalom predpriyatiya.10. 10-13 (2019)

12. A. Panfilova, Razvitie rukovoditelya kak social'nogo arhitektora. Chelovek $\mathrm{i}$ obrazovanie. 4 (21) 8-13. (2009)

13. Ya. Wang. Edutainment technology - a new starting point for education development of China. Section T1B-5, 37th ASEE/IEEE Frontiers in Education Conference. (2007). 
14. A. Popov, Marketingovye igry. Razvlekaj i vlastvuj. M. (2006).

15. A. Panfilova, N. Loginova, Vozmozhno li obuchat's serotoninom? Nauka Krasnoyar'ya. 4 (8), 69-81 (2019)

16. A.Z. Minakhmetova, O.A., Skutelnik, Y.M. Fedorchuk, Motivational and valuable orientation of teachers as a condition to form students tolerant behavior Man in India. 97(3), 323-332. (2017)

17. E. Piskunova, I. Sokolova, , A. Kalimullin, The problem of correspondence of educational and professional standards (results of empirical research). International Journal of Environmental and Science Education. 11(6), 1003-1010 (2016)

18. O. N. Shilova,: Konceptual'nyj sintez - metodologija sovremennogo pedagogicheskogo issledovanija. Chelovek i obrazovanie. 4, 18-23 (2019).

19. Ju. M. Fedorchuk, Panfilova L.G., Kuznecov A.N.: Nezavisimaja ocenka kachestva uslovij osushhestvlenija obrazovatel'noj dejatel'nosti v Rossii: problematika i normativnoe obespechenie. Chelovek i obrazovanie. 1, pp. 22-29 (2020). 